\title{
VERSORGINGSFASILITEITE WAT DIE ONAFHANKLIKHEID VAN DIE PASIËNT MET KARSINOOM BEVORDER
}

\author{
Elise S. Malan
}

\section{INLEIDING}

Die uitwerking van kanker op die mens is omvattend. Die persoon en sy gesin, sowel as die sosiale milieu waarin hulle beweeg, word hierdeur beïnvloed. Aangesien negatiewe gevoelens, gepaardgaande met vrees en onkunde, dikwels deel vorm van die persoon met kanker se beleweniswêreld, kan verpleegkundige versorgingsfasiliteite 'n bydrae lewer tot die verligting van hierdie gevoelens, asook tot die bevordering van onafhanklikheid by die persoon. Die kankergediagnoseerde persoon bevind homself te midde van 'n reeks behandelings en/of herhaalde hospitalisasie. Ten spyte van die vlak van mediese tegnologie tans, is die effek van die behandeling steeds ingrypend. Onafhanklike en self-versorgende optrede deur die persoon, hetsy in 'n vroeë of laat stadium van die siekte en behandeling, sal dus 'n bydrae lewer tot 'n verbeterde selfbeeld asook tot beheer oor die behandeling-en newe-effeksituasie.

In hierdie studie is daar gepoog om vas te stel in hoeverre bestaande versorgingsfasiliteite benut word om onafhanklikheid by die pasiënt met karsinoom te bevorder.

\section{VERSORGINGSFASILITEITE Pasiëntonderrig, leeraktiwiteite en hulpmiddele}

Donabedian glo dat die kwaliteit van 'n onderrigprogram weerspieël word in die feit dat die pasiënt 'n meer positiewe onafhanklikheidstatus bereik. ${ }^{3}$

'n Onderrigprogram wat op die kankerpasiënt gerig is, het die volgende ten doel:

- Die handhawing van sosiale rolle.

- Die aanleer van beheer oor behandelingsnewe-effekte.

- Die voorkoming van 'n totale persoonlikheidsoorweldiging deur die siekte.

- Die handhawing van sinvolle, alledaagse aktiwiteite.

Leeraktiwiteite word in ooreenstemming met elke pasiëntsituasie beplan.

Hulpmiddele kan in 'n ondersteunende hoedanigheid gedurende die onderrigsessie gebruik word. Indien hulpmiddele kreatief aangewend word, sal pasiënte meer leer, beter onthou en bepaalde vaardighede aanleer.

\section{Summary}

Since cancer is a long-term disease it has far-reaching implications for the patient. Nurse and patient are in periods during treatment. It is important to develop education programmes and community support services during these periods of close patient contact in order to lighten the burden of nursing staff and to encourage patient independence. contact with one another for prolonged

\section{GEMEENSKAPSVERPLEEGKUNDIGE VERSORGING}

Die gesondheid van die gemeenskap vorm die basis van gemeenskapsverpleging. Alhoewel die bevordering en handhawing van die gemeenskap se gesondheid die belangrikste uitgangspunt is, bly haar praktyk algemeen en komprehensief $v$ aard en steeds gerig op die individu, die gesin en groepe in die gemeenskap. Die gesondheidsprobleme van die individu affekteer sy vlak van funksionering, dit beïnvloed die res van die gesin, en die uitwerking daarvan kring uit tot die gemeenskap self. Die versorging van die individu tuis binne gesinsverband bly steeds een van haar belangrikste take.

\section{DOEL VAN DIE STUDIE}

Die doelstellings van die studie was om te bepaal

- of bestaande versorgingsfasiliteite genoegsaam benut word om onafhanklikheid by die kankerpasiênt te bevorder; en

- of die onderrig wat in die onkologiesaal en -kliniek aan die pasiënt gegee word, die hantering van behandelingsneweeffekte en onafhanklikheid bevorder

\section{HOSPIESVERSORGING}

Hospiesversorging dui op 'n kombinasie van medies-wetenskaplike kennis en menslike belange. Zimmerman definieer hospiesversorging as 'n "comprehensive program of management that offers an opportunity to provide palliative care for the terminally ill patients." ${ }^{\text {Die }}$ belangrikste doelwitte wat hier nagestreef word, kan soos volg beskryf word:

- Die maksimale vrywaring van fisiese en emosionele pyn.

- Die bevordering van 'n sinvolle lewensuitkyk.

- Die voorsiening in die pasiënt se behoeftes, veral met betrekking tot siekte, dood en rou. ${ }^{2}$

Hospiesversorging neem verskillende vorme aan. Dit sluit die volgende in:

- Tuisversorgingsdienste.

- Hospiesversorging in hospitale.

- Palliatiewe versorgingseenhede in hospitale.

- Outonome hospitiums.

Die studie is gerig tot outonome hospiesen tuisversorgingsdienste.

\section{NAVORSINGSONTWERP}

Die navorser maak gebruik van die nieeksperimentele ontwerp, en as passiewe waarnemer word daar min manipulasie buiten dit wat as voorwaardes vir die steekproefpersone gestel is, op die eksterne veranderlikes uitgeoefen. 'n Bepaalde groep se gedrag en opinies is deur middel van die opname-metode verkry.

Die volgende tegnieke is gebruik:

- Literatuurstudie.

- Observasie.

- Vraagstelling, wat die volgende insluit: - Onderhoudvoering.

Vrae- en kontrolelyste.

Bogenoemde tegnieke dek hoofsaaklik die volgende aspekte:

- Die struktuur van die onderrigprogram.

- Die proses van pasiëntonderrig.

- Tuishantering van behandelingsneweeffekte deur die pasiënt.

- Gemeenskapsdienste.

\section{STEEKPROEF}

Die pasièntpopulasie word bepaal deur van nie-waarskynlikheids- en toevallige seleksie 
gebruik te maak. Die respondente is gekies uit 'n pasiëntbevolking wat die Onkologieafdeling te Nasionale Hospitaal

Bloemfontein, gedurende die tydperk 1 Januarie tot 30 September 1985 besoek het. Hierdie metode is gekies omdat daar beter kontrole oor veranderlikes gehandhaaf kon word, alhoewel dit nie werklik verteenwoordigend van die groter populasie is nie.

Die volgende vereistes is ook gestel:

- Pasiënt moet woonagtig wees in die stad Bloemfontein.

- Slegs 'n eerste en/of tweede kankerbehandeling moes gedurende die bepaalde tydperk ontvang word.

- Die eerste en/of tweede behandeling moes in die Onkologie-saal en/of kliniek ontvang word.

- Die eerste en/of tweede behandeling moes chemoterapeuties of radioterapeuties (of albei) van aard gewees het.

- Privaatpasiënte is nie in berekening gebring nie.

Uit 'n totaal van 965 pasiënte wat die kologie-saal of -kliniek gedurende die tydperk 1 Januarie tot 30 September 1985 besoek het, was slegs $91(9 \%)$ woonagtig in die stad en distrik Bloemfontein. Slegs 18 van die 91 pasiënte voldoen aan bogenoemde vereistes. Dit gee 'n steekproef van $19,8 \%$.

Die ontleding van die pasiëntdata was soos volg:

- Ouderdomme wissel tussen 12 en 80 jaar.

- Gemiddelde ouderdom: 44,4 jaar

- Ses van die pasiënte kon om verskeie redes nie gekontak word nie, wat 'n oorblywende getal van $12(13,2 \%)$ pasiente as steekproef laat.

\section{NAVORSINGSBEVINDINGS}

Struktuur van die pasiëntonderrigprogram

Die data wat tydens die evaluering van die anderrigprogram se struktuur versamel is rd soos volg saamgevat:

- Die personeel word nie effektief aangewend vir pasiëntonderrig nie.

- Die beskikbare tyd word nie effektief ten opsigte van pasiëntonderrig benut nie.

- Die beskikbare hulpmiddels word nie benut ten einde onderrig te bevorder nie.

- Die roetine van die saal en kliniek maak nie voorsiening vir ' $n$ bepaalde tyd wanneer daar pasiëntonderrig gegee kan word nie.

\section{Proses van pasiëntonderrig}

Die versamelde data word soos volg uiteengesit:

- Hoofsaaklik fisiese faktore word in die beraming van die pasiëntsituasie beklemtoon.

- Die verpleegkundige of geneesheer bepaal pasiëntbehoeftes eensydig, en daar word aan die hand daarvan onderrig gegee.

- Die fisiese omgewing word nie tydens pasiëntonderrig as 'n bepalende faktor in ag geneem nie.
- Die inhoud van die leerstof beklemtoon hoofsaaklik die behandelingsmetode en moontlike newe-effekte daarvan.

- Kennis word op ' $n$ individuele wyse oorgedra.

- Slegs gedrukte materiaal word as oudio-visuele hulpmiddels gebruik.

- Evaluering van pasiëntleeraktiwiteit is wel moontlik in die saal, maar nie in die kliniekopset nie.

Tuishantering van behandelingsneweeffekte en benutting van gemeenskapsdienste

- Soos reeds aangedui, is bogemelde steekproef uitgevoer op pasiënte wat slegs een of twee kankerbehandeling ontvang het. Op sigself dui dit op 'n ligte graad van behandeling wat noodwendig ' $n$ invloed sal hê op die hewigheid van die newe-effekte wat ervaar word.

- Alhoewel $92 \%$ van die ondervraagdes wel kennis gedra het van die behandelingsnewe-effekte, het slegs 18\% inligting ontvang in verband met die tuishantering daarvan.

- 33\% van die pasiente het aangedui dat die newe-effekte hul tuis baasraak, desondanks het geeneen die Onkologieafdeling om hulp genader nie.

- Daar bestaan wel onder die ondervraagdes 'n behoefte om tot 'n selfhelpgroep te behoort.

- Die Gemeenskapsverpleegkundige besoek die kankerpasiënt om ander redes as kanker en die hantering van newe-effekte.

\section{AANBEVELINGS}

Struktuur van die pasiëntonderrigprogram

1. Ten opsigte van die kliniek

- Daar moet 'n aparte lokaal, uitsluitlik vir pasiëntonderrig en wat ook toegerus is met oudio-visuele materiaal, ingerig word.

- Die roetine van die kliniek moet so gewysig word dat 'n bepaalde tyd afgesonder word vir pasiëntonderrig.

- Die plekbespreking van pasiënte behoort oordeelkundig te geskied ten einde meer eweredige pasiëntverspreiding te verseker.

2. Ten opsigte van die saal

Die struktuur van pasiëntonderrig kan op die volgende maniere verbeter word:

- Daar moet voorsiening gemaak word vir groter privaatheid tydens pasiëntonderrig.

- Die verpleegkundige moet genoeg tyd aan die pasiënt spandeer.

- Personeel moet meer effektief aangewend word deur bloot die beskikbare personeel meer eweredig oor die aantal diensure per dag te versprei. Die onderstaande opmerkings het betrekking op die saal sowel as die kliniek:

- Daar moet 'n onderrigprogram opgestel word wat in die totale behoeftes van die kankerpasiënt voorsien.

- Daar moet 'n verpleegkundige aangewys word vir spesifiek pasientonderrig, en wat terselfdertyd dien as skakel tussen die pasiënt en ander spanlede (onder andere die geneesheer, maatskaplikewerker, radiografiste, fisioterapeut en arbiedsterapeut)

\section{Proses van pasiëntonderrig}

Leeraktiwiteite van die pasiènt kan

bevorder word deur die volgende:

- 'n Deeglike beraming van die pasiëntsituasie kan gedoen word deur volledige inligting te bekom van:

die pasiënt se primêre bron, gebaseer op waarnemings en

onderhoudvoering as basiese metodes om hierdie inligting te bekom; en

- gesinslede, ander gesondheidspersoneel, mediese en sosiale rekords as sekondêre bronne

- Die versamelde data moet objektief geanaliseer word om leerbehoeftes by die pasiënt te bepaal en die leerproses aan te moedig.

- Verwagte korttermyngevolge moet deel vorm van elke onderrigsessie.

- Daar moet langtermyndoelstellings in die onderrigprogram ingewerk word.

- Die verpleegkundige en pasiënt moet gesamentlik besluite neem in verband met verwagte gevolge.

- Die keuse van die onderriginhoud moet in bepaalde behoeftes van die pasiënt voorsien.

- Die onderriginhoud moet uitgebrei word om die volgende aspekte in te sluit.

- die patofisiologie van die betrokke karsinoom;

- die verskillende behandelingsmetodes wat van toepassing is;

- die tydsduur van elke behandelingsmetode;

- die moontlike newe-effekte;

- die tuishantering van die neweeffekte; en

- die benutting van gemeenskapsdienste.

- Die volgende onderrigmetodes moet in die proses gebruik word:

— informele onderrig;

- gestruktureerde onderrig (bespreking, demonstrasie).

- Die bestaande hulpmiddels moet aangevul word om die volgende in te sluit:

- klankskyfie reeks;

- films;

- modelle; en

- prente/plakkate.

- Die pasiënt se kennis tydens en na elke onderrigsessie moet geëvalueer word deur middel van:

- vraagstelling;

- die invul van 'n vraelys; en

- demonstrasie deur die pasiênt.

- Daar moet in die pasiëntonderrigprogram voorsiening gemaak word vir evaluering van die terapeut se:

- teoretiese kennis:

- vaardighede; en

- houding.

- Die pasiëntonderrigprogram moet van tyd tot tyd herevalueer word (prosesevaluering). 
Tuishantering van behandelingsneweeffekte en die benutting van gemeenskapsdienste

Ten opsigte van bogenoemde kan die gemeenskapsverpleegkundige haar dienste verbeter deur die volgende:

- Die pasiënt moet van meet af ingelig word aangaande beskikbare gemeenskapsdienste asook hoe en wanneer om van die dienste gebruik te maak.

- Daar moet groter koördinasie tussen die bestaande dienste waarin die verpleegkundige en maatskaplike werker 'n kernrol kan speel, bewerkstellig word.
- Die gemeenskapsverpleegkundige moet direk betrek word ten einde kontinuiteit in die sorg van die pasient vanuit die hospitaal of kliniek, asook tuis, te verseker.

\section{BRONNELYS}

1. Miller J.F. 1982. Categories of self-care needs of ambulatory patients with diabetes. Journal of Advanced Nursing 7: 25-31.

2. Perrollaz L.E., Mollica M. 1981. Public knowledge of Hospice Care. Nursing Outlook Jan; 46-48.

3. Redman B.K. 1984. The process of patient education. St. Louis; C.V. Mosby Co.

4. Uys H.M.M., Basson A.A. 1983. Navorsingsmetodologie in die verpleegkunde. Pretoria: Opvoedkundige Uitgewers.

5. Zimmerman J.M. 1986. Hospice complete care for the terminally ill. Baltimore: Urban and Schwarcenberg.

Elise S. Malan
B.SOC. SC. (Verp.), B.SOC. SC. HONN
(Verp), M.SOC. SC. (Gemeenskapsverp),
GAV., GVV., GPV., GVV.,
Geregistreerdedosent

